\title{
Work Overload and Emotional Exhaustion in University Teachers: Moderating Effects of Coping Styles*
}

\section{Sobrecarga de trabajo y agotamiento emocional en profesores universitarios: Efectos moderadores de los estilos de afrontamiento}

\author{
José A. García-Arroyo a \\ Universidad de Educación a Distancia (UNED), \\ España \\ ORCID: http://orcid.org/0000-0001-9905-1374 \\ Amparo Osca Segovia \\ Universidad de Educación a Distancia (UNED), \\ España \\ ORCID: http://orcid.org/0000-0003-3210-689X
}

a Correspondence author. Email:

joseantoniogarciaarroyo@gmail.com

How to cite: García-Arroyo, J. A., \& Osca, A. (2019). Work overload and emotional exhaustion in university teachers: Moderating effects of coping styles. Universitas Psychologica, 18(2), 1-12. https://do i.org/10.11144/Javeriana.upsy18-2.woee

\begin{abstract}
Changes in the education system in Ecuador have increased the workload of university teachers, producing stress and burnout. This study analyses the relation between work overload, coping styles and emotional exhaustion in a sample of 202 university teachers by using a hierarchical regression model analysis. The results show that work overload and evasive coping are positively related to emotional exhaustion, while active coping is negatively related to emotional exhaustion. Evasive coping moderated the relationship between work overload and emotional exhaustion so that teachers who use more evasive coping in situations of high work overload experience less burnout than teachers who use this coping style less. Finally, we discuss the limitations of this study and its theoretical and practical contributions for university professors in Latin American contexts.

Keywords

work overload; emotional exhaustion; active coping; evasive coping; university teachers.

\section{RESUMEN}

Los cambios en el sistema educativo de Ecuador han contribuido a un aumento de la sobrecarga de trabajo de los docentes universitarios produciendo estrés y burnout. Este estudio analiza la relación entre la sobrecarga de trabajo, los estilos de afrontamiento y el agotamiento emocional en una muestra de 202 profesores universitarios mediante modelos de regresión jerárquica. Los resultados muestran que la sobrecarga de trabajo y el afrontamiento evasivo están positivamente relacionados con el agotamiento mientras que el afrontamiento activo está relacionado negativamente. Además, el afrontamiento evasivo modula la relación entre la sobrecarga y el agotamiento de forma que los docentes que emplean mucho afrontamiento evasivo en situaciones de elevada sobrecarga experimentan menos agotamiento. Finalmente se discuten las
\end{abstract}


limitaciones del estudio y sus implicaciones teóricas y prácticas para los docentes universitarios en contextos latinoamericanos.

Palabras clave

sobrecarga laboral; agotamiento emocional; afrontamiento activo; afrontamiento evasivo; docentes universitarios.

The change in working conditions and, in particular, work overload is an important and representative source of occupational stress in the literature on stress (Laurence, Fried, \& Raub, 2016). Among many other reasons, overload may occur due to the new legal or market demands, the introduction of new technologies, staff adjustments and reorganization. In Ecuador, the new Organic Law of Higher Education (2010) and the application of its Rules of Procedure (Consejo de Educación Superior, 2012) have produced changes that involve greater demands and overload affecting the work situation of the university teachers. These changes can lead to the appearance of stress symptoms and emotional exhaustion. Emotional exhaustion is considered to be the heart of the burnout (Seidler, et al., 2014) and also the most widely reported dimension of the syndrome; therefore, we focused on this dimension. It refers to feelings of emotional emptiness and a decrease of personal resources as a result of long exposure to situations of chronic occupational stress (Leiter \& Maslach, (2016).

To study work overload and emotional exhaustion is very important because they are associated with relevant outcomes such as job satisfaction and motivation to quit (Skaalvik \& Skaalvik, 2017), student's quality of motivation (Shen et al., 2015) and performance (Huyghebaert, 2018). They can influence not only the teacher's quality of life but also the quality of teaching and the academic preparation of future professionals. The aim of this study is twofold. First, we analyze the relationship between the stress produced by work overload and emotional exhaustion, and second, we examine the role of coping styles in this relationship.
It is also worth noting that we present the results of one sample of university teachers from Ecuador. The relationship between coping and burnout has hardly been studied in Latin America (Austria, Cruz, Herrera, \& Salas, 2012; Ortiz-Buttazzoni \& Menghi, 2017). Specifically, we have only found two studies with Ecuadorian samples. The first by Ilaja and Reyes (2016) that analyzed the mediating effect of health and emotional intelligence between stress and burnout in a sample of 60 teachers and the second by García-Arroyo and Osca (2017) that analyzed the relationships between the conjoint use of active and evasive coping, and burnout. In addition, there are few studies in educational contexts and even less in university contexts (Jiang, Du, \& Dong, 2017), which makes it more relevant to analyze, since the relationship between exhaustion and coping can vary between teaching levels (Carson, Tsouloupas, \& Barber, 2012)

\section{Work overload and stress}

Stress, produced by work factors, refers to the contents of work itself and the tasks carried out in the work settings (Nguyen \& Ermasova, 2018). It displays, both in quantitative and qualitative terms, especially in work overload situations associated with systems to increase quality, a higher demand for training, and the increasing use of information and communication technology applied to work tasks. The literature examined for this study links work overload to physical and psychological health problems. Evidence of the relation between work overload and burnout has also been found in samples of different professions such as members of health care staff (Deodhar \& Goswami, 2017), nursing staff (Grigorescu, Cazan, Grigorescu, \& Rogozea 2018), pharmaceutical industry employees (Andrews \& Kacmar, 2014), or occupational therapists (Paulsen et al., 2014), to name a few.

In the field of teaching and education, the meta-analysis carried out by Montgomery and 
Rupp (2005) with 65 studies on stress in teachers, revealed a strong association between the teachers' stressors, work overload, and burnout. Another more recent meta-analysis (García-Arroyo, Osca, \& Peiró, 2019) also found a positive association between work overload and burnout in teachers from 36 countries. According to Marrau (2004), job insecurity, especially in temporary or part-time teachers, leads them to an overload of work, trying to become irreplaceable, which generates a high level of chronic stress that usually causes symptoms of burnout. There is much evidence of the positive relationship between overload and burnout (e.g., Abbas \& Roger, 2013; De Beer, Pienaar, \& Rothmann, 2016). However, some studies have not found this relation. For example, Chennoufi, Ellouze, Cherif, Mersni, and M'rad (2012), in a study with teachers of public secondary schools, found that $75.2 \%$ of the sample reported overload as a factor of occupational stress, but there was no significant association between work overload and the burnout syndrome.

Similarly, Gomes and Dos (2011) found that teachers with high work overload presented symptoms of depression, but they did not report significant associations between work overload and burnout, concluding that the symptoms of burnout could be due to the influence of other variables. Despite this indicated lack of consistency in the results, it seems that the most intuitive opinion positively relates work overload to emotional exhaustion. Therefore, we propose the following hypothesis:

Hypothesis 1: Work overload will be positively related to emotional exhaustion.

\section{Coping strategies and emotional exhaustion}

According to Lazarus and Folkman (1991), coping strategies are behavioral and cognitive efforts carried out to deal with, reduce, or tolerate the internal and external demands generated by stressful events. These authors point out two basic styles of coping strategies: those aimed at changing the situation, trying to modify the stressor, which are called active or direct; and those that are aimed at regulating the emotional response generated by the stressor, which are referred to as evasive, indirect, or palliative. Examples of the former are: trying to control the situation or the problem, seeking and assessing alternatives to solve it, taking cost-benefit into account, modifying the pressures, procedures or resources, or reducing the participation of the self. Examples of the latter would be avoidance, distancing, or positive comparisons (GarcíaArroyo \& Osca, 2017).

Research shows that more direct coping strategies or strategies aimed at problem solving are positively related to psychological health (e.g., Austria et al., 2012; Mark \& Smith, 2012). However, there is less consensus about the more indirect strategies or strategies aimed at managing emotions, which, in some cases, are linked to lower psychological well-being (Mark $\&$ Smith, 2012), but not in all situations (Chen, Ma, \& Zhu, 2014; Lin, Probst, \& Hsu, 2010). For example, a study with pediatric critical care staff notes that a high percentage of variation in burnout is predicted by frequent use of emotion-focused coping style and infrequent use of problem-center coping style (Rodríguez-Rey et al., 2019). Nevertheless, Dewe and Trenberth (2004) highlight that the lack of agreement is related to the complexity of the concept and the multiple ways of conceptualizing and measuring it. Besides, it is connected to the need for matching the coping strategies to the features of the stressor or to the situation in which it occurs.

In the university educational setting, Chan (2011) observed that active coping increases satisfaction and the feeling of personal accomplishment and reduces emotional exhaustion. On the other hand, Guerrero (2003) found that teachers who resort to passive or evasive coping strategies show higher levels of emotional exhaustion. Similarly, Mazon, Carlotto, and Câmara (2008) reported that greater use of coping strategies focusing on emotions led to higher levels of emotional exhaustion. Comparable results were reported by David and Quintao (2012), who observed that teachers who used strategies focused primarily on emotion experienced higher levels of burnout. 
Taking into account all these findings, we propose the following two hypotheses:

Hypothesis 2: Active coping will be negatively related to emotional exhaustion.

Hypothesis 3: Evasive coping will be positively related to emotional exhaustion.

In the Latin American background, we found some studies with samples of university teachers from Colombia, Mexico, and Peru. These studies mainly analyzed the prevalence of burnout (e.g., Ibañez, Bicenty, Thomas, $\mathcal{E}$ Martínez, 2011 ; Rojas $\&$ Grisales, 2011) and the coping styles most commonly used (Garay, Farfán, \& Moysen, 2010; Valadez, Bravo, \& Vaquero, 2011), which are usually the active-focused coping styles such as confrontation, planning or seeking social support.

Some studies have analyzed the moderating effect of coping, although the results are not conclusive. For example, some authors (Peters et al., 2016) in a longitudinal study with nurses found no significant moderating effects of active coping in the relationship between work demands and emotional exhaustion. However, other authors (Peltokorpi, 2018), also in longitudinal studies, did find that the evasive coping moderated the relationship between abusive supervision and subordinates' emotional exhaustion.

Moreover, some studies with double interactions show that it is appropriate to combine both the active and the evasive strategies (García-Arroyo \& Osca, 2017). In the same way, we analyzed the moderating role of coping strategies, expecting that coping would act especially in situations of high overload. Lastly, we addressed the study of the joint effect of the two coping strategies, as it is presumed that coping will be more efficacious when combining both strategies, active and evasive, simultaneously. Based on this, we propose the two following hypotheses:

Hypothesis 4: Coping will play a moderating role in the influence of overload on emotional exhaustion, and this will be particularly evident in situations of high overload.

Hypothesis 5: Coping will play a moderating role in the influence of overload on emotional exhaustion so that, in the face of high overload situations, the conjoint use of both coping strategies will be more efficacious.

\section{Method}

Procedure

Sample selection was incidental and participation in this study was voluntary. The data were collected in various public and private universities of the city of Guayaquil (Ecuador). We used a questionnaire that was individually administered at times that did not affect the teachers' work schedule. Before administering the questionnaire, participants received instructions on how to complete it and were ensured of the confidentiality of their responses and the ethical treatment of the data. We had to reject some questionnaires (16\% of the total received) because they were uncompleted or incorrectly filled.

\section{Participants}

The final sample was made up of 202 teachers from Ecuadorian universities, of whom $73 \%$ were male and $27 \%$ were female. Their mean age was 46.5 years $(S D=12.5)$. Regarding the academic level, $75.9 \%$ have a four-level degree (master or Ph.D.), and $24.1 \%$ have a third level degree. They had been teaching in the university for an average of 12.3 years $(S D=11.3)$, and $58.6 \%$ work in public universities and $41.4 \%$ work in private universities.

\section{Instruments}

We used the Spanish version of the Occupational Stress Inventory (OSI; Cooper, Sloan, \& Williams, 1988). To measure work overload, we selected 8 items of the sub-scale Work Factors, specifically those related to work overload (example item: "I have too much work to do"). The items were rated on a 6-point Likert scale, ranging from 1 (It is not at all a source of pressure) 
to 6 (It is definitely a source of pressure). Reliability of this scale was appropriate $(\alpha=$ 0.72). Emotional exhaustion was assessed with 5 items from the Maslach Burnout Inventory General Survey (Schaufeli, Leiter, Maslach, \& Jackson, 1996). An example item is: "I feel emotionally exhausted by my work" rated on a frequency scale ranging from 0 (Never) to 6 (Every day). The alpha Cronbach for this scale was $\alpha=0.86$. To measure coping, we used 17 items from the OSI scale, regrouped through factor analysis (with varimax extraction and rotation method) in the two theoretical dimensions of Dewe (Dewe, \& Trenberth, 2004): active coping ( 8 items; $\alpha=0.76$; item example: Using selective attention to focus on specific problems) and evasive coping (9 items; $\alpha=$ 0.70; item example: Postponing the problem and putting it aside). The response scale ranges from 1 (I never use it) to 6 (I use it frequently).

\section{Data Analysis}

To test the hypotheses of the study and verify whether the relations between work overload and burnout are direct or moderated by active and evasive coping, we run a hierarchical regression model, as recommended to determine the interaction effect (Cohen, Cohen, West, \& Aiken, 2003). Specifically, in the first step, we entered the years of university teaching experience as a control variable; in the second step, work overload; in the third step, coping styles (active and evasive); in the fourth step, the double interactions between the stressor and the two styles of coping. Lastly, in the fifth step, the triple interaction between the stressor, active coping and evasive coping.

\section{Results}

The correlation analysis shows that work overload is positively related to emotional exhaustion, supporting hypothesis 1. Active coping is negatively related to emotional exhaustion supporting hypothesis 2. However, no significant relationship between evasive coping and emotional exhaustion was found, leading us to reject hypothesis 3. There is a positive and significant relationship between work overload and evasive coping, and also between the two coping styles with each other. The results further indicate that when teaching experience increases, work overload and emotional exhaustion decrease. Table 1 presents the means, standard deviations, and correlations between the variables.

\section{Table 1}

Means, standard deviations and correlations

\begin{tabular}{llcccccccc}
\hline \multicolumn{1}{c}{ Variables } & Scale & Items & Mean & SD & $\mathbf{2}$ & $\mathbf{3}$ & $\mathbf{4}$ & $\mathbf{5}$ \\
\hline 1 & Teaching experience & - & - & 12.3 & 11.31 & $-0.13^{*}$ & 0.02 & -0.06 & $-0.26^{* * *}$ \\
2 & Work overload & $1-6$ & 7 & 3.47 & 0.96 & & -0.06 & $0.23^{* * *}$ & $0.20^{* *}$ \\
3 & Active coping & $1-6$ & 8 & 5.06 & 0.69 & & & $0.30^{* * *}$ & $-0.28^{* * *}$ \\
4 & Evasive coping & $1-6$ & 9 & 3.87 & 0.82 & & & 0.10 \\
5 & Emotional exhaustion & $1-6$ & 5 & 1.86 & 1.39 & & & \\
\hline \multicolumn{6}{c}{$* p<0.05, * * p<0.01, * * *$} & $p<0.001$ &
\end{tabular}

The regression results to predict emotional exhaustion are presented in table 2 .

The control variable teaching experience, $F$ $(1,190)=13.54, p<0.001$, was significant explaining $6 \%$ of the variance of emotional exhaustion. Work overload $(\beta=0.17, p<$ $0.05)$, increased the explained variance to $9 \%$. Both active coping $(\beta=-0.31, p<0.001)$ and evasive coping $(\beta=0.15, p<0.05)$ were significant, increasing the explained variance to $18 \%, F(4,187)=10.81, p<0.001$. These results confirm that these three variables contribute in the prediction of emotional exhaustion. In step IV, the interaction between work overload and evasive coping was significant $(\beta=-0.67, p$ $<0.10), F(6,185)=7.70, p<0.001$, increasing the explained variance to $20 \%$. These results support hypothesis 4 . However, the triple interaction between work overload, active coping and evasive coping was non-significant, leading us to reject hypothesis 5 . 
Table 2

Regression analysis to predict emotional exhaustion

\begin{tabular}{|c|c|c|c|c|c|}
\hline \multirow{2}{*}{ Variables } & \multicolumn{5}{|c|}{ Steps } \\
\hline & I & II & III & IV & $\mathbf{v}$ \\
\hline Teaching experience & $-0.25 * * *$ & $-0.23^{* *}$ & $-0.22 * *$ & $-0.22 * *$ & $-0.22 * *$ \\
\hline Work overload & & $0.17^{*}$ & 0.11 & 0.25 & 0.49 \\
\hline Active coping & & & $-0.31 * * *$ & $-0.47 \dagger$ & $-0.45 \dagger$ \\
\hline Evasive coping & & & $0.15^{*}$ & $0.50^{*}$ & $0.51^{*}$ \\
\hline Work overload $\mathrm{x}$ active coping & & & & 0.37 & 0.12 \\
\hline Work overload $\mathrm{x}$ evasive coping & & & & $-0.67 \dagger$ & -0.98 \\
\hline $\begin{array}{l}\text { Work overload } \mathrm{x} \text { active coping } \mathrm{x} \\
\text { evasive coping }\end{array}$ & & & & & 0.32 \\
\hline$F$ & $13.54 * * *$ & $9.90^{* * * *}$ & $10.81^{* * *}$ & $7.70^{* * *}$ & $6.58 * * *$ \\
\hline$R^{2}$ & 0.06 & 0.09 & 0.18 & 0.20 & 0.20 \\
\hline$\Delta R^{2}$ & $0.06 * * *$ & $0.03^{*}$ & $0.09 *$ & $0.02 \doteqdot$ & 0.00 \\
\hline
\end{tabular}

Figure 1 shows the moderating effect of evasive coping on work overload. The use of evasive coping reduces emotional exhaustion when work overload increases. Thus, in situations with low work overload, there are no significant differences in the level of exhaustion between people who use high evasive coping and those who use low evasive coping, but when the work overload is high, the teachers who use low evasive coping are more tired than teachers who use a high evasive coping.

\section{Figure 1}

Modulated relationship between work overload and evasive coping to predict burnout.

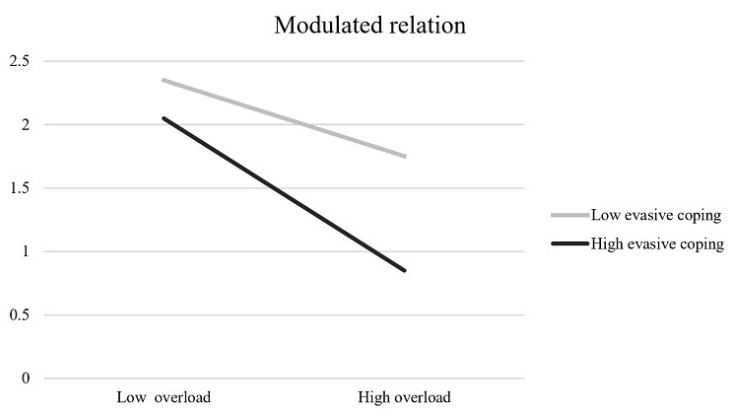

\section{Discussion}

The aim of this study was twofold. First, we analyzed the relationship between the stress produced by work overload and emotional exhaustion, and second, we examined the role of coping styles in this relationship. To fulfill these general objectives, five hypotheses were tested about the relationship between work overload, active and evasive coping, and emotional exhaustion. As expected, work overload is positively and significantly related to emotional exhaustion, supporting the first hypothesis. These results are consistent with many of the studies reviewed in which university teachers with higher work overload also had higher levels of burnout (e.g., Abbas \& Roger, 2013; Tripken, 2012).

Hypotheses 2 and 3 relate coping styles with emotional exhaustion. A significant negative relationship was found between active coping and emotional exhaustion; however, evasive coping was not significant. These results coincide with those by NowakowskaDomagala, Jablkowska-Gorecka, KostrzanowskaJarmakowska, Mortoń and Stecz (2015) who found that task-oriented coping was negatively correlated with exhaustion and found no correlation between the symptoms of exhaustion and avoidance-oriented coping. They also agree with previous studies in relation to the beneficial effect of active coping (Chan, 2011; Palacio, Caballero, González, Gravini, \& Contreras, 2012) so that facing the problem directly helps to reduce exhaustion. These results also indicate that the direct relationship between evasive coping and exhaustion is not clear, as previous study results had shown, although they do support the moderating role this coping style may have.

The results found in Ecuadorian teachers are similar to those found in teachers who are not Latin American. This allows us to state that in the sample studied, the effect of coping strategies on health, and specifically on burnout, coincides with the results obtained to date in most European or American contexts and countries. Nevertheless, these results differ from presented by Ramírez et al. (2018) with samples of health professionals in Ecuador. These authors found that the use of more passive coping was associated with a higher probability of presenting exhaustion. The occupation can explain this difference. According to some authors (GarcíaArroyo \& Osca 2018), health professionals 
may experience very demanding situations that produce high exhaustion. However, they have more highly structured and defined procedures to perform their tasks than teachers and therefore, the effect of evasive coping on exhaustion is different in each profession.

Hypothesis 4 analyzed the moderating role of coping in the relationship between work overload and emotional exhaustion and proposed that this effect would be particularly evident in situations of high overload. Our results show that when work overload is high, teachers who use more evasive coping styles are less tired than those who use evasive coping infrequently. No evidence of moderating effect on the active coping style was found. From this, we can understand that active coping acts directly reduce exhaustion. For example, a teacher will reduce emotional exhaustion when using active strategies directly related to work overload, such as organizing schedules or distributing tasks to be performed. However, evasive styles, such as seeking distractions or social support, will not reduce exhaustion directly but will moderate the stressor's effect.

In this way, although evasive coping has been related to the decline of psychological health, it can be beneficial in stressful situations thanks to its moderating effect. Thus, for coping styles to be effective, they must adapt to the situation. To be more precise, while active coping seeks to change the stressful situation, evasive coping is effective when it is difficult to change the situation or the stressors. For example, Oren (2012) notes that active coping is useful for employees with high levels of autonomy and control, but for those with limited capacity of control, active coping may be counterproductive for health due to the extra effort involved.

Lastly, we found no evidence of the triple interaction between work overload, active coping, and evasive coping. Probably since, in our sample, overload and emotional exhaustion report low rates as well as very high active coping scores, which are very effective in a direct mode and at the same time reduce the possibility of significant interaction effects. Thus, unfortunately, hypothesis 5 was not confirmed.

\section{Limitations}

Although these results are interesting, we must point out some limitations of the study. The first one refers to the sociodemographic characteristics of our sample. The male and long-experienced representation of teachers is predominant. In our study, we used the teaching experience as a control variable. However, it should be noted that other sociodemographic variables have been related to exhaustion in some studies such as sex (Purvanova \& Muros, 2010), age, or the public or private state of the teaching institution (Álvarez Flores, 2007), although results on the effect of these variables are not conclusive. Therefore, it would be interesting to include sociodemographic factors in future studies.

Second, our study analyses emotional exhaustion, assuming it as the core dimension of burnout (Seidler et al., 2014). However, it would be interesting to include depersonalization and personal accomplishment as the other two dimensions of burnout in order to have a broader understanding of this syndrome in future studies. Furthermore, in addition to emotional exhaustion, it would also be advisable to introduce variables related to the quality of work, since teachers who use more positive coping styles have more positive reactions in their interaction with students (Buettner, Jeon, Hur, \& Garcia, 2016).

Third, our study relates coping styles with work overload. However, to analyze in more depth the adaptive nature of coping styles it would be interesting to include other predictor variables that some authors have already tested in future studies, such as social support (Shimazu, Shimazu, \& Odara, 2005), the ability to control (Mark \& Smith, 2012) or professional selfefficacy, since they have proven to be important predictors of exhaustion in teachers (Aloe, Amo, \& Shanahan, 2014).

Fourth, our results are based on cross-sectional data but do not show the outcomes these phenomena can produce over time. For this reason, it would be interesting for future studies 
to include longitudinal data and compare them with the results already obtained by some authors (Rodríguez, Kozusznik, Peiró, \& Tordera, 2019).

\section{Practical implications}

From the results, some significant proposals to be considered from an applied point of view. First, the negative relationship between experience in teaching and exhaustion means that teachers with little experience are more tired. It is important to address the health and well-being of all teachers, but especially those who have less experience because they are more vulnerable.

Second, since overload is an important stressor directly related to burnout, it is necessary to examine the workload of teachers and do proper planning of tasks and schedules.

Third, in order to reduce exhaustion, copying must be active when its action can change the stressful situation as it acts directly on exhaustion. However, if the stressful situation cannot be changed, it is better to do more evasive coping because it acts indirectly by moderating the effect of the stressor.

Fourth, in order to improve the health of teachers and thus facilitate the teaching activity, universities and educational centers should control work overload and program prevention plans aimed at training teachers in the use of coping styles. Some authors have already reported results on the effectiveness of certain practices, for example, training in emotion management (Kinman, Wray, \& Strange, 2011) or training in the experience of gratitude and happiness (Chan, 2011).

Finally, we conclude that this study contributes to the knowledge of the quality of life and working conditions of Ecuadorian teachers because, to date, studies on the styles of exhaustion and coping in Ecuadorian samples are scarce.

\section{Disclosure statement}

The authors reported no potential conflict of interest. This research did not receive any specific grant from funding agencies in the public, commercial, or not-for-profit sectors.

\section{References}

Abbas, S. G., \& Roger, A. (2013). Impact of overload and coping strategies on stress \& burnout of university teachers. Workshop on Research Advances in Organizational Behavior and Human Resources Management, 2013, Paris, France. Retrieved from https://hal-univ-lyon3.arch ives-ouvertes.fr/hal-00958210

Aloe, A. M., Amo, L. C., \& Shanahan, M. E. (2014). Classroom management selfefficacy and burnout: A multivariate metaanalysis. Educational Psychology Review, 26(1), 101-126. https://doi.org/10.1007/s10 648-013-9244-0.

Álvarez Flores, D. (2007). Satisfacción y fuentes de presión laboral en docentes universitarios de Lima. Persona, 10, 49-97. Retrieved from http://www.redalyc.org/arti culo.oa?id=147112813004

Andrews, M. C., \& Kacmar, K. M. (2014). Easing employee strain: The interactive effects of empowerment and justice on the role overload-strain relationship. Journal of Behavioral and Applied Management, 15(2), 43-58. Retrieved from https://www.questia. com/library/journal/1P3-3232814681/easin g-employee-strain-the-interactive-effects-o $\mathrm{f}$

Austria, F., Cruz, B., Herrera, L., \& Salas, J. (2012). Relaciones estructurales entre estrategias de afrontamiento y síndrome de Burnout en personal de salud: un estudio de validez externa y de constructo. Universitas Psychologica, 11(1), 197-206. https://doi.org /10.11144/Javeriana.upsy11-1.reea

Buettner, C. K., Jeon, L., Hur, E., \& Garcia, R. E. (2016). Teachers' socialemotional capacity: Factors associated with teachers' responsiveness and professional commitment. Early Education and Development, 27(7), 1018-1039. https:/ /doi.org/10.1080/10409289.2016.1168227 
Carson, R. L., Tsouloupas, C. N., \& Barber, L. K. (2012). Burnout and coping strategies across primary and secondary publicschool teachers. In C. J. McCarthy, R. G. Lambert, \& A. Ullrich (Eds.), International perspectives on teacher stress (pp. 195-218). Greenwich, Connecticut: Information Age Publishing, Inc.

Chan, D. (2011). Burnout and life satisfaction: Does gratitude intervention make a difference among chinese school teachers in Hong Kong? Educational Psychology, 31 (7), 809-823, https://doi.org/10.1080/01 443410.2011 .608525$.

Chennoufi, L., Ellouze, F., Cherif, W., Mersni, M., \& M'rad, M. F. (2012). Stress and burnout among tunisian teachers. L'Encéphale, 38(6), 480-487. https://doi.org/10.1016/j.e ncep.2011.12.012.

Chen, S., Ma, J., \& Zhu, J. (2014). Relation of job burnout to locus of control and coping style in higher vocational college teachers. Chinese Mental Health Journal, 28(4), 293-297. Retrieved from https://caod.oriprobe.com/articles/41 504627/Relation_of_job_burnout_to_locu s_of_control_and_co.htm

Cohen, J., Cohen, P., West, S. G., \& Aiken, L. S. (2003). Applied multiple regression/ correlation analysis for the behavioral sciences. Mahwah, NJ: Lawrence Erlbaum Associates Publishers.

Consejo de Educación Superior. (2012). Reglamento de carrera y escalafón del profesor e investigador del sistema de educación superior. Registro oficial RPCSO-037-N№. 265-2012. Ecuador.

Cooper, C. L., Sloan, S. L., \& Williams, S. (1988). Occupational Stress Indicator Management Guide. Windsor: NFER- Nelson.

David, I. C., \& Quintao, S. (2012). Burnout in teachers: Its relationship with personality, coping strategies and life satisfaction. Acta Medica Portuguesa, 25(3), 145-155.

De Beer, L. T., Pienaar, J., \& Rothmann, S. Jr. (2016). Work overload, burnout, and psychological ill-health symptoms: a threewave mediation model of the employee health impairment process. Anxiety, Stress E3 Coping, 29(4), 387-399. https://doi.org/1 $0.1080 / 10615806.2015 .1061123$

Deodhar, J. K., \& Goswami, S. S. (2017). Structure, process, and impact of a staff support group in an oncology setting in a developing country. Industrial psychiatry journal, 26(2), 194-200. https://doi.org/10.4 103/ipj.ipj_59_16

Dewe, P., \& Trenberth, L. (2004). Work stress and coping: drawing together research and practice. British Journal of Guidance and Counseling, 32(2), 143-156. https://doi.org/ 10.1080/03069880410001692201

Garay, J., Farfán, M.C., \& Moysen, A. (2010). Afrontamiento en un grupo de docentes universitarios. Interpsiquis 2010: $11^{\circ}$ Congreso virtual de Psiquiatría. Retrieved from http://hdl.handle.net/10401/957

García-Arroyo, J., \& Osca, A. (2017). Coping with burnout: Analysis of linear, non-linear and interaction relationships. Anales de Psicología, 33(3), 722-731. http://dx.doi.org /10.6018/analesps.33.3.279441

García-Arroyo, J., \& Osca, A. (2018). Effect sizes and cut-off points: a meta-analytical review of burnout in latin American countries. Psychology, health $\mathscr{E}$ medicine, 23(9), 1079-1093. https://doi.org/10.1080/ 13548506.2018.1469780

García- Arroyo, J. A., Osca, A., \& Peiró, J. M. (2019). Meta-analytical review of teacher burnout across 36 societies: the role of national learning assessments and gender egalitarianism, Psychology 83 Health, 34(6), 733-753. https://doi.org/10.1080/08870446 .2019 .1568013

Gomes, A. P. R., \& dos, R. Q. (2011). Burnout, satisfaçäo com a vida, depressäo e carga horária em professores. Análise Psicológica, 29(2), 335-344. https://doi.org/10.14417/a p.56

Grigorescu, S., Cazan, A. M., Grigorescu, O. D., \& Rogozea, L. M. (2018). The role of the personality traits and work characteristics in the prediction of the burnout syndrome among nurses-a new approach within predictive, preventive, and personalized 
medicine concept. EPMA Journal, 9(4), 355-365. https://doi.org/10.1007/s13167-0 18-0151-9

Guerrero, E. (2003). Análisis pormenorizado de los grados de burnout y técnicas de afrontamiento del estrés docente en profesorado universitario. Anales de Psicología, 19(1), 145-158.

Huyghebaert, T., Gillet, N., Beltou, N., Tellier, F., \& Fouquereau, E. (2018). Effects of workload on teachers' functioning: A moderated mediation model including sleeping problems and overcommitment. Stress and Health: Journal of the International Society for the Investigation of Stress, 34(5), 601-611. https://doi.org/10.1002/smi.2820

Ibañez, E., Bicenty, A., Thomas, Y., \& Martínez, J. (2011). Prevalencia y factores asociados al Síndrome de Burnout en docentes de odontología Fundación Universitaria San Martín, año 2011. Revista Colombiana de Enfermería, 7(7), 105-111. https://doi.org/1 0.18270/rce.v7i7.1453

Ilaja, B., \& Reyes, C. (2016). Burnout y estrategias de inteligencia emocional en profesores universitarios: Implicaciones en la salud laboral educativa. Psicología desde el Caribe, 33(1), 31-46. https://doi.org/10.144 82/psdc.33.1.8081

Jiang, X. R., Du, J. J., \& Dong, R. Y. (2017). Coping style, job burnout and mental health of university teachers of the millennial generation. Journal of Mathemmatical Science and Technology Education, 13(7), 3379-3392. https://doi.or g/10.12973/eurasia.2017.00734a

Kinman, G., Wray, S., \& Strange, C. (2011). Emotional labour, burnout and job satisfaction in UK teachers: the role of workplace social support. Educational Psychology, 31(7), 843-856, https://doi.org/ 10.1080/01443410.2011.608650.

Laurence, G. A., Fried, Y., \& Raub, S. (2016). Evidence for the need to distinguish between self-initiated and organizationally imposed overload in studies of work stress. Work E Stress, 30(4), 337-355. https://doi.o $\mathrm{rg} / 10.1080 / 02678373.2016 .1253045$
Lazarus, R. S., \& Folkman, S. (1991). The concept of coping. In A. Monat \& R. S. Lazarus (Eds.), Stress and coping: An anthology.(3rd ed., pp. 189-206). New York, NY: Columbia University Press.

Leiter, M. P., \& Maslach, C. (2016). Latent burnout profiles: A new approach to understanding the burnout experience. Burnout Research, 3(4), 89-100. https://doi. org/10.1016/j.burn.2016.09.001

Lin, H., Probst, J. C., \& Hsu, Y. (2010). Depression among female psychiatric nurses in southern Taiwan: Main and moderating effects of job stress, coping behavior and social support. Journal of Clinical Nursing, 19(15-16), 2342-2354. https://doi.org/10.1111/j.13652702.2010.03216.x

Mark, G., \& Smith, A. P. (2012). Effects of occupational stress, job characteristics, coping, and attributional style on the mental health and job satisfaction of university employees. Anxiety, Stress $\mathbb{E}$ Coping: An International Journal, 25(1), 63-78. https://doi.org/10.1080/10615806.2 010.548088

Marrau, C. (2004). El síndrome de burnout y sus posibles consecuencias en el trabajador docente. Fundamentos de Humanidades, 5(10), 53-68. Retrieved from https://dialnet.unirioja.es/servlet/artic ulo? codigo $=2004369$

Mazon, V., Carlotto, M. S., \& Câmara, S. (2008). Síndrome de burnout e estratégias de enfrentamento em professores. Arquivos Brasileiros de Psicologia, 60(1), 55-66. Retrieved from http://pepsic.bvsalud.org/scielo.php?s cript $=$ sci_arttext\&pid $=$ S1809-526720080 00100006

Montgomery, C., \& Rupp, A. A. (2005). A metaanalysis for exploring the diverse causes and effects of stress in teachers. Canadian Journal of Education, 28(3), 458-486. https: //doi.org/10.2307/4126479.

Nguyen, L. D., \& Ermasova, N. (2018). Task, relationship and work overload stress orientations of Russian and Dutch 
working adults: does gender make a difference? International Journal of Business and Emerging Markets, 10(4), 341-359. http s://doi.org/10.1504/IJBEM.2018.095711

Nowakowska-Domagala, K., JablkowskaGorecka, K., Kostrzanowska-Jarmakowska, L., Mortoń, M., \& Stecz, P. (2015). The interrelationships of coping styles and professional burnout among physiotherapists: a cross-sectional study. Medicine, 94(24), e906. https://doi.org/10.1 097/MD.0000000000000906

Oren, L. (2012). Job stress and coping: selfemployed versus organizationally employed professionals. Stress and Health: Journal of the International Society for the Investigation of Stress, 28(2), 163-170. https://doi.org/10 $.1002 /$ smi. 1418

Ortiz-Buttazzoni, P. D., \& Menghi, M. S. (2017). Clima social escolar percibido y síntomas del síndrome de Burnout en profesores de nivel secundario $=$ School social climate perception and symptoms of burnout syndrome in secondary school teachers. Acta Psiquiátrica y Psicológica de América Latina, 63(2), 96-103. Retrieved from https://www.researchgate.net/profile/ Maria_Menghi2/publication/329650384_ Clima_socio_escolar_percibido_y_sintoma s_del_sindrome_de_Burnout_en_profesor es_de_nivel_secundario/links/5c13a4f6928 51c39ebec9) $\overline{\mathrm{fb}} 8 /$ Clima-socio-escolar-percibi do-y-sintomas-del-sindrome-de-Burnout-e n-profesores-de-nivel-secundario.pdf

Palacio, J. E., Caballero, C. C., González, O., Gravini, M., \& Contreras, K. P. (2012). Relación del burnout y las estrategias de afrontamiento con el promedio académico en estudiantes universitarios. Universitas Psychologica, 11(2), 535-544. https://doi.org /10.11144/Javeriana.upsy11-2.rbea

Paulsen, A. A., Meredith, P., Khan, A., Henderson, J., Castrisos, V., \& Khan, S. R. (2014). Burnout and work engagement in occupational therapists. The British Journal of Occupational Therapy, 77(3), 156-164. https://doi.org/10.4276/03080221 4X13941036266621
Peltokorpi, V. (2018). Abusive supervision and emotional exhaustion: the moderating role of power distance orientation and the mediating role of interaction avoidance. Asia Pacific Journal of Human Resources. htt ps://doi.org/10.1111/1744-7941.12188

Peters, V., Houkes, I., de Rijk, A. E., Bohle, P. L., Engels, J. A., \& Nijhuis, F. J. (2016). Which resources moderate the effects of demanding work schedules on nurses working in residential elder care? A longitudinal study. International journal of nursing studies, 58, 31-46. https://doi.org/10 $.1016 /$ j.ijnurstu.2016.01.008

Ramírez, M. R., Otero, P., Blanco, V., Ontaneda, M. P., Díaz, O., \& Vázquez, F. L. (2018). Prevalence and correlates of burnout in health professionals in Ecuador. Comprehensive psychiatry, 82, 73-83. https:/ /doi.org/10.1016/j.comppsych.2017.11.011

Rodríguez, I., Kozusznik, M. W., Peiró, J. M., \& Tordera, N. (2019). Individual, co-active and collective coping and organizational stress: A longitudinal study. European Management Journal, 37(1), 86-98. Retrieved from https://limo.libis.be/ primo-explore/fulldisplay?docid=LIRIAS1 998710\& context $=$ L\&vid $=$ Lirias\&search _scope $=$ Lirias $\&$ tab $=$ default_tab\&lang $=\mathrm{e}$ n_US\& fromSitemap $=1$

Rodríguez-Rey, R., Palacios, A., Alonso-Tapia, J., Pérez, E., Álvarez, E., Coca, A., ...Gómez, F. (2019). Burnout and posttraumatic stress in paediatric critical care personnel: Prediction from resilience and coping styles. Australian Critical Care, 32(1), 46-53. https ://doi.org/10.1016/j.aucc.2018.02.003

Rojas, M. L., \& Grisales, H. (2011). Burnout Syndrome in professors from an academic unit of a colombian university. Investigación y Educación en Enfermería, 29(3), 427-434. Retrieved from http://www.scielo.org.co/pd f/iee/v29n3/v29n3a11.pdf

Schaufeli, W. B., Leiter, M. P., Maslach, C., \& Jackson, S. E. (1996). Maslach Burnout Inventory: General survey. In C. Maslach, S. E. Jackson \& Leiter, M. P. (Eds.), The Maslach Burnout Inventory. RTest manual 
(pp. 1-52). (3rd. ed). Palo Alto Ca.: Consulting psychologist Press.

Seidler, A., Thinschmidt, M., Deckert, S., Then, F., Hegewald, J., Nieuwenhuijsen, K., \& Riedel-Heller, S. G. (2014). The role of psychosocial working conditions on burnout and its core component emotional exhaustion-a systematic review. Journal of occupational medicine and toxicology, 9(1), 10. https://doi.org/10.1186/1745-6673-9-1 0

Shen, B., McCaughtry, N., Martin, J., Garn, A., Kulik, N., \& Fahlman, M. (2015). The relationship between teacher burnout and student motivation. British Journal of Educational Psychology, 85(4), 519-532. htt ps://doi.org/10.1111/bjep.12089

Shimazu, A., Shimazu, M., \& Odara, T. (2005). Divergent effects of active coping on psychological distress in the context of the demands-control-support model: the roles of job control and social support. International Journal of Behavioral Medicine, 12(3), 192-198. https://doi.org/10.1207/s15 327558 ijbm1203_8

Skaalvik, E. M., \& Skaalvik, S. (2017). Motivated for teaching? Associations with school goal structure, teacher selfefficacy, job satisfaction and emotional exhaustion. Teaching and Teacher Education, 67, 152-160. https://doi.org/10.1016/j.tate. 2017.06.006

Tripken, J. L. (2012). An analysis of stress, burnout, and coping in a sample of secondary public-school teachers (Unpublished doctoral thesis). ProQuest Information $\mathcal{G}$ Learning. Dissertation Abstracts International: Section B: The Sciences and Engineering. Retrieved from https://www.semanticscholar.org/pap er/An-analysis-of-stress\%2C-burnout $\% 2 \mathrm{C}$ and-coping-in-a-of-Tripken/b1d17e29bc4f a46655cbe 5c8f58f870ea00a98cb

Valadez, A., Bravo, M.C., \& Vaquero, J. (2011). Estrategias de afrontamiento empleadas por docentes universitarios. Revista electrónica de Psicología Izcateca, 14(1), 65-76.
Retrieved from http://www.revistas.unam. mx/index.php/repi/article/view/24794

\section{Notes}

* Research article. 